\title{
Anne Fleming's History of Law and Consumer Finance
}

\author{
VICTORIA BARNES
}

\section{Introduction}

This review article does not set out to retell the story of Anne Fleming's life in a chronological fashion, but rather it engages intellectually with the themes in Anne's scholarship. Anne's passing means that her thoughts, guidance, and encouragement are lost to the scholarly communities of which she was a part. Over the course of her career, Anne offered sage advice, she helped others to develop their work, and she supported them wherever she could. ${ }^{1}$ Now, there will no longer be that voice in the conference room, the office, or the lecture hall. We will not know how her presence would have influenced the field in the years to come and how her engagement with other scholars would have shaped them. So I write to gather together the ideas within Anne's work, hoping to provide a fuller set of insights than can be gleaned by reading pieces of her scholarship individually. This integrated and coordinated view is the sort of comprehensive thinking that she would have given in her interactions.

Given that my aim here is both a professional and personal one, this also means that I will follow another unconventional pattern that those writing life stories actively discourage: I will refer to Anne by her first

(c) The Author(s), 2021. Published by Cambridge University Press on behalf of the Business History Conference. All rights reserved.

doi:10.1017/eso.2021.12

VICTORIA BARNES is a senior research fellow at the Max Planck Institute for European Legal History, Frankfurt, Germany. She works on the history of business, its form and regulation in law and society. Her recent work can be read in the Journal of Corporation Law, Hastings Business Law Journal, Company Lawyer, and the Journal of Legal History. E-mail: barnes@rg.mpg.de

I am grateful to Felice Batlan, Claire Brennecke, Liz Harmon, Lucy Newton and Andrew Popp for their comments and suggestions on an earlier draft. This article has benefited from discussions with Rosemary Auchmuty, Ed Balleisen, Matilde Cazzola, Neil Rollings, Stefan Vogenauer, Emily Whewell and Sarah Wilson.

1. To get a view of Anne's supportiveness, one might look to the student comments on Georgetown University's dedicated webpage, "In Memoriam: Professor Anne Fleming," https://www.law.georgetown.edu/news/in-memoriam-professoranne-fleming/. Having worked in the office next to Anne's in 2016, I can say without hesitation that these tributes are correct. 
name throughout. This is not anachronistic. I knew Anne simply as Anne. By doing this, I hope that it may be easier to engage with a strong, insightful, and supportive voice that has now been lost. Although this piece has a biographical aim, it is not littered with personal remarks or anecdotes. The theory and methodology of biographical scholarship is now sufficiently developed that it has a critical component rather than hagiographic aim. Academic writers should no longer retell the life story of the "great and the good." It is now customary and, indeed, even expected that authors-including those writing In Memoriashould avoid narrating a story of heroes and heroines. They should comment on all aspects of one's character, not just those of positive note. ${ }^{3}$ The absence of such a personal commentary in this case should not be read to mean that I have adopted this "other" format in order to avoid writing objectively. ${ }^{4}$

There are other resources that offer insights into Anne's personality, manner, and her style; they remark keenly on her interactions with others and the esteem in which she was held. Her colleagues as Climenko Fellows have authored a piece, ${ }^{5}$ Dan Ernst's tribute appears in the first few pages of the recent issue of the Georgetown Law Review, ${ }^{6}$ and Edward Balliesen has written in the Business History Conference's Exchange blog. ${ }^{7}$ Of all of these sources, most notable are the entries on Georgetown Law's In Memoriam webpage and also on the Legal History Blog. ${ }^{8}$ The latter is authored by the leading legal historians Dan Ernst, Mitra Sharafi, and Karen Tani. The In Memoriam webpage is reflective and open for others to comment. As it has been used in this way frequently and continues to be updated, this piece has a life force of its own. The notes placed there from friends, colleagues, and students capture Anne's character perfectly. ${ }^{9}$ No static single authored piece can claim to improve upon it.

This article has three sections. It begins by briefly explaining the issues at the core of Anne's research and the subjects of her scholarly

2. Auchmuty and Rackley, "Feminist Legal Biography"; Barnes, MacMillan, and Vogenauer, "On Legal Biography."

3. See, for instance, Cownie's work on Claire Palley. Cownie, "United Kingdom's First Woman Law Professor."

4. Quite honestly, I do not have anything negative to say-and if I did, this piece would be far easier to write. As her colleague Professor David Super said: Anne "may be the only member of the faculty about whom I have never heard a single negative word.” Georgetown University webpage, "In Memoriam: Professor Anne Fleming."

5. Harvard Law Today webpage, “"The scholar, teacher, and colleague we should all hope to be': Anne Fleming '05 (1979-2020),” https://today.law.harvard.edu/annefleming-05-legal-historian-past-climenko-fellow/.

6. Ernst, "In Memoriam: Professor Anne C. Fleming In Memoriam."

7. Balleisen, "In Memoriam: Anne C. Fleming, 1979-2020."

8. Ernst, Sharafi, and Tani, "Anne Fleming: In Memoriam."

9. Georgetown University webpage, "In Memoriam: Professor Anne Fleming." 
focus. It addresses not only what she had published thus far but also what Anne had planned for the future. This is followed by a section that considers her unique methodology. It does so by comparing and contrasting various different approaches and their disciplinary guises. The final part considers the historiographic debates for which Anne's work had most significance. Anne made a central contribution to several bodies of scholarship. I outline three key themes and the questions that Anne's work spoke to most definitively, although her work touched on many other areas of research.

\section{Focus}

Anne's academic gaze was almost universally focused on legal issues involving individuals in poverty. Her first published note considered the termination of tenancy agreements of mentally disabled tenants in federally subsided housing. ${ }^{10}$ She looked at the legal issues that affected working-class households through the lens of contract law and consumer law. This meant that she investigated policy making as well as law. Her later work considered the regulation of lending at the fringes, which is otherwise thought of in different temporal or international contexts as the business of loan sharks, payday lending, salary loans, and small-sum loans. Although Anne had published her monograph City of Debtors only three years ago, in $2018,{ }^{11}$ she looked to embark on a new research project.

While Anne had not yet published her new research on consumer bankruptcy law, she had discussed some of these ideas with colleagues and had begun to present them at conferences. She planned to examine the new system of consumer bankruptcy, which became Chapter 13 of the Bankruptcy Act. To do this, she explored bankruptcy docket books from the 1930s. Her early research on this project focused on Alabama. In doing so, she highlighted inequalities in race, class, and gender. Race and discrimination were important and logical components when looking at the legal history of poverty in this region. She intended to show Chapter 13's origins in the American South and looked to use this background to explain some of the system's deviations from past practices. She would have written about how Chapter 13 effectively exported nationwide one region's highly segregated attitudes toward consumer debt and its forgiveness. With its use of mapping software, this was a different style of research; but this project was a natural next

10. Fleming, "Protecting the Innocent."

11. Fleming, City of Debtors (Harvard). 
step for her. It stemmed from Anne's interest in civil liberties and civil rights as well as poverty.

\section{Approach}

Anne's methods caught attention. Banking historian Sharon Ann Murphy described Anne's approach as one of "uniqueness." ${ }^{12}$ Indeed, Anne combined law with business history profitably. For those historians interested in the economy and society, in particular, Anne's work had the highest appeal. Anne explained that her style was integrating "the 'bottom-up' approach of social historians with the 'top-down' perspective of traditional legal and political history." ${ }^{13}$ Anne was not interested in communicating only with those in the law field in a somewhat "internal" manner; she aimed explicitly and clearly to engage with "external" audiences and with the methods of other disciplines. ${ }^{14}$

This open approach can be seen throughout her work. Her work on the leading American case Williams v. Walker-Thomas Furniture Co. $(1965)^{15}$ was not the typical law review piece, but it could well have been. ${ }^{16}$ Her article focused on the legal principles surrounding unconscionability. The doctrine of unconscionability allowed courts to overturn agreements where parties had unequal bargaining power and the agreement was favorable to the stronger party. ${ }^{17}$ Anne utilized her strengths as a business historian to dig deep into the archival record of the leading cases and the case law. With that, she built a new "narrative" of the events. ${ }^{18}$ Anne, like most historians, recognized that she was engaged in the construction of historical narratives. ${ }^{19}$ Her article on legal doctrine and Williams v. Walker-Thomas Furniture Co. (1965) remains, at this point in time, her most cited piece. ${ }^{20}$

12. Murphy, "Up Close and Personal with the American Debtor."

13. Fleming, "City of Debtors" (Enterprise \& Society), 738.

14. Elsewhere, the approach, which Anne avoided, has been described less favorably. In the United States "internal” legal history is labeled "law office history." The terms "black letter" or "doctrinal legal history" pervade and are synonyms, although "doctrinal legal history" is generally thought to be less pejorative in the United Kingdom, at least. See Lewis and Lobban, Law and History.

15. 350 F.2d 445 (D.C. Cir. 1965).

16. For the differences in legal history in a law review and legal history journal, see Stern, "Proximate Causation in Legal Historiography."

17. It is not recognized in all common law jurisdictions. See the historical and comparative analysis in Waddams, "Unconscionability in Contracts."

18. Fleming, "Rise and Fall of Unconscionability," 1384.

19. Popp and Fellman, "Writing Business History." See also Durepos, McKinlay, and Taylor, "Narrating Histories of Women at Work."

20. At the time of this writing, Google Scholar shows seventy-five citations. 
For all of her interdisciplinary work, openness to using nonlegal methods and speaking to those in different disciplines, Anne was undoubtedly a legal scholar at heart, and an exceptional one at that. Anne's chapter on legal history and economic history in the Oxford Handbook of Legal History focused on how economic history could be brought into debates in legal history. ${ }^{21}$ Of course, one might well see matters in the opposite direction on which discipline was at the core of the debate and which at the periphery, ${ }^{22}$ but, for Anne, law was center stage. In Anne's research on the history of mandatory disclosure rules in lending, she revealed a history that had been forgotten. ${ }^{23}$ History thus gave new insights into contemporary legal questions and other ways of approaching the same question. She did not seek to unpick the intellectual or contextual background of law or unearth the motivations behind the ruling of judges, as others had done using the method of judicial biography. ${ }^{24}$ She analyzed law not on the ideas behind it or in a way that might re-create the legal debate between opposing counsel in the courtroom. ${ }^{25}$

How did Anne analyze the history of consumer law? Anne focused on law's impact on people and groups. ${ }^{26}$ It is for this reason that Anne's work was held in such high esteem by business historians. Her focus was plainly and clearly on the consumers themselves. ${ }^{27}$ She did not, for example, venture into quantitative studies or adopt the macroapproach of law and economics. ${ }^{28}$ Anne explained the circumstances in which individuals came to seek a payday loan, why they could not repay it, and when a legal case for default was filled and how it unfolded. The life stories of litigants were recounted personally, recreating the social life of the borrower and their communities. ${ }^{29}$ Anne was able to weave together a story of legal rules that had failed to protect vulnerable individuals with key debates in legal history, business history, and economic history.

21. Fleming, "Legal History As Economic History."

22. Barnes, Bottomley, and Küsters, "Economic History as Legal History."

23. Fleming, "Long History of 'Truth in Lending."”

24. One might look to Karsten's work as the key text in this area. See Karsten, Heart versus Head.

25. For a study of unconscionability from this perspective, see Posner, "Contract Law in the Welfare State.”

26. For overview of a similar approach and the historiography of critical legal studies, see Salojärvi, "Counter-Culture of Law."

27. Anne's method was both innovative and different but also explicit, as business historians recommend. Decker, Kipping, and Wadhwani, "New Business Histories!"

28. Harris, "Encounters of Economic History and Legal History"; de Jong and Higgins, "New Business History?"

29. Fleming, "Borrower's Tale." 


\section{Themes}

Anne's scholarship also advanced several substantive claims about the history of lending, the state's role in protecting the poor, and the regulation of capitalism, more generally. This section proceeds to consider each of these points in turn. Her work added much to these discrete areas of research, but it was equally powerful in terms of recalibrating trends and the direction of future scholarship.

\section{A Social History of Finance}

First, Anne's work made a distinctive impact on financial history. For those looking for a more traditional firm- or sector-level approach to banking, Anne's work said little. It is difficult to build a debate about facts or their interpretation between Anne's scholarship and, for example, the recent work of Louis Hyman or Scott Reynolds Nelson, or the stalwart texts on American banking by Howard Bodenhorn or Eugene White. ${ }^{30}$ As one reviewer, Simone Selva, said of the book City of Debtors, "[d]espite what the title might imply, this book does not add to the banking history of modern America. It contains neither a statistical survey of small banks, lending institutions, and intermediary moneylenders, nor detailed case studies of such institutions. Likewise, the author does not examine the monetary and banking technicalities of the lending transactions that she depicts." 31 It would be perhaps difficult to engage in this-especially for the types of businesses in Anne's study. This would be, after all, a business history of loan-sharking.

To have engaged in a study of these firms would have been an analysis of how lenders marketed themselves to this segment of consumers; that is, to customers experiencing financial hardship or were otherwise faced with destitute circumstances. ${ }^{32}$ It would have also involved studying the process through which these lenders assessed creditworthiness (and then based on that assessment, charged borrowers exorbitant rates of interest). ${ }^{33}$ Enforcement mechanisms and their effectiveness (e.g., suing the debtor or their employer for

30. Hyman, Debtor Nation; Nelson, Nation of Deadbeats; Bodenhorn, History of Banking in Antebellum America; White, Regulation and Reform.

31. Selva, review of City of Debtors, 880.

32. For more general on bank marketing, see Reveley and Singleton, "Clearing the Cupboard"; Barnes and Newton, "Symbolism in Bank Marketing and Architecture"; Barnes and Newton, "Women, Uniforms and Brand Identity in Barclays Bank."

33. Newton, "Trust and Virtue in English Banking”; Olegario, Engine of Enterprise. 
nonrepayment) would have been considered. ${ }^{34}$ I am not sure what the readership for such a book might be. Anne would either have had to have written a history to help future loan sharks improve their business or to have understood firm growth. Business growth would have been due to excessively high rates of interest and aggressive enforcement mechanisms. High profits from these endeavors was at the expense of the end user-it pushed those on the breadline further into poverty. As Anne put it: we might "consider the rules that determine how the fruits of American capitalism are distributed across the spectrum of American households, leaving some to teeter on a tightrope while others are granted a wider, surer path to prosperity." ${ }^{35}$ Anne placed these firms and their activities into the context of American society.

Anne's focus on the consumer and society as opposed to the firm was engaging. Studies in banking history that use an explicit Chandlerian framework are rare, ${ }^{36}$ although management accounting techniques (and their link to firm growth or economic stability) are usually the subject of examination. ${ }^{37}$ Anne did not follow these traditional routes. She showed that, for the most part, those who sought payday loans were working-class individuals who found themselves in desperate need of quick money; and they struggled to deal with lenders, who pressed the advantage of unequal bargaining power. ${ }^{38}$ It is often not clear why loan applicants sought credit, and if this was granted, what the loan was used for. ${ }^{39}$ The social context of banking is essential in understanding the way in which the industry operated and how lenders came to function in the way that they did. This socio-economic context is much stronger when looking to the business history literature on savers rather than debtors. ${ }^{40}$

\section{State and Regulation}

Second, Anne added much to the debate about the state's role in protecting consumers. This was a shift from the dominant debate in finance

34. Guinnane, "Regional Organizations in the German Cooperative Banking System"; Rubin, "Bills of Exchange, Interest Bans, and Impersonal Exchange."

35. Fleming, City of Debtors (Harvard), 253.

36. There are very few banking histories that use an explicit Chanderlian framework. For an example of one, see Collins, "Growth of the Firm in the Domestic Banking Sector."

37. See Collins and Baker, Commercial Banks and Industrial Finance; Cassis, Crises and Opportunities; Calomiris and Haber, Fragile by Design.

38. Fleming, "Borrower's Tale."

39. Two examples follow businesses borrowers as opposed to consumer borrowers. See Newton, "Regional Bank-Industry Relations ”; Scott, "Interwar British Hire Purchase."

40. Wadhwani, "Citizen Savers.” See also Scott and Newton, “Advertising, Promotion." 
and economics, which hitherto focused on how the state might regulate banking in order to produce economic growth. ${ }^{41}$ The legal scholar Mehrsa Baradaran explained in her review of City of Debtors that "what this particular fight and Fleming's illuminating history reveal is the space between justice and liberty in a free market economy. What is the meaning of freedom to contract for desperate borrowers on the fringe with limited options? And short of more robust reforms ensuring economic equality, can the sharpest edges of capitalism be constrained by law?" 42 It is not always clear when the state should intervene in private agreements. ${ }^{43}$ The view that courts should protect individuals, but thus also curb their freedoms, was hotly contested both through time and space.

Indeed, Anne considered freedom to contract in the guise of lending at rates above the usury laws in the Lochner era. The case of Lochner v. New York (1905) ${ }^{44}$ closely resembled the litigation Anne examined between borrowers and loan sharks. The case became so influential in legal thinking that its name now defines an era of law making, with Lochner being commonly used to describe the period at the turn of century. Much work has been devoted to studying the intellectual historical element, ${ }^{45}$ rejection of class legislation, ${ }^{46}$ Social Darwinism and the survival of the fittest mentality, ${ }^{47}$ and its impact in other regions of the United States. ${ }^{48}$ As Victoria Nourse said in 2009, "the Lochner era's conception of fundamental rights parallels that of today." 49 This legal underpinning can be seen in Anne's doctoral work that later became City of Debtors. Anne saw her PhD dissertation as offering a historical lens into the issues raised by People by Schneiderman v. Western Sky Financial, LLC et al. (2014). ${ }^{50}$ The case involved a contract for a loan with excessively high interest rates that were well above the legal limit. The legal question concerned the court's role in overturning a private agreement. What role should the state have to regulate these disputes? Should it even have one? Why should it intervene? The contract had, after all, been signed and agreed by both parties. Anne explained that "such

41. Mitchener, "Supervision, Regulation, and Financial Instability”; Calomiris and Haber, Fragile by Design.

42. Baradaran, review of City of Debtors.

43. Barnes, "Judicial Intervention."

44. 198 U.S. 45 (1905).

45. Sunstein, "Lochner's Legacy."

46. Gillman, Constitution Besieged; Bernstein, “Bolling, Equal Protection, Due Process."

47. Bernstein, "Lochner Era Revisionism."

48. Clark, "Southern and Western Prehistory."

49. Nourse, "Tale of Two Lochners," 751.

50. Summary of settlement, No. $451370 / 2013$ (N.Y. County Supreme Court, Jan. $24,2014)$. 
questions have arisen repeatedly over the past century in different forums and have continued to challenge policymakers." ${ }^{51}$

Anne neither offered a solution to these policy questions nor a simplistic answer on how to fix and regulate finance. ${ }^{52}$ These were tricky questions. She remarked that "to policymakers, small-sum lending has exemplified both the promise and the perils of modern American capitalism for low-income households." ${ }_{53}$ In other words, there were arguments to be had on both sides. Anne's analysis struck a balance between, on the one hand, the social benefit that these lenders provided and, on the other hand, the moral hazard of allowing the consumer to take on further debts. There was also in Anne's mind a sharp and clear distinction between the past and present. She believed that "although the past cannot foretell the future, it does reveal some obstacles that may lie ahead. It shows that governing small-sum lending has been difficult from the very beginning and that recent struggles are rooted in old challenges." ${ }^{54}$ Anne did not see history as offering neat stories of regulatory success or failure that might be learned from. The legal contestations over liberty to contract were reoccurring historic debates, but not necessarily ones that could be instructive for the present. Anne offered a cautionary note to those who looked to use the past for future purposes.

The political scientist Howard Schweber explained the importance of such a distinction when he distinguished between "law school historiography" and "law office history." "Practitioners of law office history," he said, "cherry-pick the historical record to support a position in a current controversy. Law school historiography does not imply any similar motivation. The impulses involved are directed toward academic scholarship." This scholarly literature, Schweber commented, appears "to be motivated by the construction of a certain kind of historical narrative, one that accords with the author's ideas about how 'law' works and develops." ${ }_{55}$ Anne unpacked pivotal moments and explained path dependency in the way a historian might. ${ }^{56}$ It was to this wider historiographic debate that she contributed the most. Anne's scholarship deepened our understanding of the period rather than using the past to deploy arguments for the present. Anne's written work dealt with "historiography," as Scheweber notes. Yet, on a professional level, Anne also had an eye to present-day law and policy making and used her knowledge of the past in these discussions. As an attorney, Anne represented homeowners facing foreclosure and later, as a legal

51. Fleming, "City of Debtors" (Enterprise \& Society), 735.

52. Schnapp, review of City of Debtors.

53. Fleming, City of Debtors (Harvard), 10.

54. Fleming, City of Debtors (Harvard), 251.

55. Schweber, "Challenge of Legal Historiography," 246-247.

56. Fleming, "Public Interest in the Private Law of the Poor." 
academic, she was also involved in commenting on the legal work undertaken by those at the Consumer Financial Protection Bureau. ${ }^{57}$

Even so, in tracing the lives of those on the weaker end of the contractual bargain, Anne said much that should be noted by policy makers. Anne's work, which explained pathways to litigation, emphasized the vulnerability of borrowers. It showed understanding and compassion, revealing that borrowers were destitute and in desperate need for a quick loan, often through no fault of their own. Anne, in sum, suggested that these individuals needed to be protected. It equally noted that consumers did not know their legal position; there were key intermediaries who acted to advise individuals and protect them from rogue traders. Today, we might think of the Consumer Financial Protection Bureau, in the United States, and of Which? or of Citizen's Advice in the United Kingdom, as obvious examples. These entities are, of course, recent additions in an era of consumer rights and increasing class-based legal protections. Anne's work spoke of the historic forerunners in consumer advocacy, legal representation, and access to justice, such as the Consumer Federation of America and the National Consumer Law Center. Murphy noted the importance of legal intermediaries in Anne's work. She said that "Fleming's is a legal history told mainly from the point of view of the debtors and their legal advocates, with the purveyors of fringe finance largely reacting to this consumer advocacy." 58 These advocates were not always lawyers.

David Sugarman notes that the traditional dichotomy between the worlds of law and business means that lawyers were more involved in business dealings than has traditionally been acknowledged. ${ }^{59}$ Recent work, however, has also challenged our definition of advocacy and widened it beyond lawyers and those in the legal profession. Felice Batlan explains that in the first half of the twentieth century it was not lawyers that helped those in poverty; it was in fact those who were not legally trained and, in particular, it was women. These individuals offered legal advice to working-class households. ${ }^{60}$ Anne said more about the negotiation of everyday economic relationships than legal principles. She did not investigate invisible means of regulation, such as a code of professional ethics, corporate social responsibility,

57. My thanks go to Liz Harmon for discussing this point with me. See also Georgetown Law, "Professor Anne Fleming: The Past as Prologue," https://www. law.georgetown.edu/news/professor-anne-fleming-the-past-as-prologue/

58. Murphy, "Up Close and Personal with the American Debtor."

59. Sugarman, "Simple Images and Complex Realities." This relationship is better recognized in the history of railway companies. See Kostal, Law and English Railway Capitalism; Benidickson, "Aemilius Irving."

60. Batlan, "Birth of Legal Aid." 
transaction costs, or internal market mechanisms, as others have. ${ }^{61}$ Here, her work spoke of people rather than "soft law" and other faceless regulatory forces. As the legal historian David Tanenhaus noted, Anne showed that creating more law was not seen by those at the time as the answer to remedy regulatory failure. He said that Anne's article showed that market participants "looked beyond the state for solutions, relying instead on other market participants and corporate employers to police the small-sum lending industry." 62

\section{Capitalism and State-level Economic Governance}

Finally, the relationship between law and economics has changed over time, and Anne saw future research in this area being one that focused on capitalism as a unit of analysis. Capitalism, on the one hand, has been a topic of discussion among business historians more generally, and it was central in Anne's work. Others, such as Barbara Hahn, on the other hand, argue that the history of capitalism agenda bears similarity to the aims of previous generations of scholarship, which used a Marxist frame. ${ }^{63}$ Some also question whether this qualitative method has the empirical component to substantiate claims about systematic industrial and economic development. ${ }^{64}$ Anne considered "capitalism" as a broader concept and a framework for analysis, and engaged with this critique.

To analyze capitalistic endeavors, Anne used the concepts of justice, equality, and fairness. In her monograph, Anne wrote: "For decades, little loans have troubled Americans because they raise a big, vexing policy question: what is the meaning of justice within capitalism?" ${ }^{65} \mathrm{In}$ other work, Anne commented that the term "capitalism" was challenging to use owing to its broad, all-encompassing nature. She argued that "the tendency of recent work to disaggregate capitalism into its many varieties—such as war capitalism and corporate capitalism-indicates that the analytic work done by 'capitalism' alone is limited." ${ }^{66}$ Anne advocated "drilling down to the specifics, setting aside the abstraction of 'capitalism,' and instead focusing on how particular capitalist societies operate and especially on how law allocates decision-making authority among economic actors." 67 Justice was, therefore, equated to decision making, and Anne was interested in the body or person that

61. See Carnevali, “'Crooks, Thieves, and Receivers.”

62. Tanenhaus, "In This Issue,” vi.

63. Hahn, review of Emperors of New Clothes.

64. Hilt, "Economic History, Historical Analysis"; O’Sullivan, "Intelligent Woman's Guide to Capitalism."

65. Fleming, City of Debtors (Harvard), 3.

66. Fleming, "Legal History As Economic History," 216.

67. Fleming, "Legal History As Economic History," 216. 
was given those decision-making powers. When looking to payday lending, economic actors in Anne's story were not only individuals but also regulators at the state and federal levels. She played with this dichotomy and the overlapping functions and interplay at both levels.

Anne noted that "to date, historians of law and modern American capitalism have underemphasized the challenges of state-level economic governance in the modern era." ${ }^{68}$ She thought that her work showed "what insights can be gleaned by exploring this unfamiliar terrain, chronicling the history of modern American capitalism within federalism." 69 She was documenting "how each generation of Americans has redefined the meaning of justice within capitalism for those on the economic margins." ${ }^{70}$ Delehanty, in his review of City of Debtors, said that "Fleming's discussion of federalism is at its best in the final chapter when she turns her attention to the post-1970 period." 71 Anne would have probably agreed with this. This chapter was also carefully blended with a discussion of changes in the banking system that led borrowers to struggle to access finance. The process of deregulatory federalism not only allowed interstate lending but also permitted banks to circumvent the usury laws and, in effect, to charge the level of interest that they liked. ${ }^{72}$ Banks moved toward higher-income borrowers through the introduction of credit cards because this form of credit involved a lower cost to the bank..$^{73}$ Branch closures also resulted in low-income consumers seeking finance from alternative sources. ${ }^{74}$ This meant that "so-called 'fringe' lending is no longer marginal," and Anne added that "it has become a staple of mainstream American capitalism."75 Payday lending ceased to be a concern for individual states; the potential furthering of economic inequality had thus become a problem for the nation as a whole.

\section{Conclusion}

This article has teased out Anne's interests and the overarching themes in her research. It shows how these themes and interests influenced the

68. Fleming, City of Debtors (Harvard), 6.

69. Fleming, City of Debtors (Harvard), 7.

70. Fleming, City of Debtors (Harvard), 3.

71. Delehanty, review of City of Debtors, 1.

72. Fleming, City of Debtors (Harvard), 240-244.

73. Fleming, City of Debtors (Harvard), 225-226.

74. Fleming, City of Debtors (Harvard), 226, 235.

75. This sentence never made it into the book; it was contained in the epilogue section of the dissertation that later became the concluding chapter in the book. The epilogue brought the 1970s and 1980s up to the present day. See Fleming, "City of Debtors" (dissertation). 
direction of her research in the hope that these ideas will continue to be influential in the years to come. Her scholarship tells a compelling story of individual lives, consumerism, and the pitfalls of leaving capitalism unbowed. The significance of Anne's scholarship is not only owing to her substantive claims but also to her approach. She mapped out elaborate histories of lending, although she primarily assessed consumer finance law and economic policy by looking at their impact on the end user. There is much to be gained by taking such an approach and from using the consumer as a lens to examine banking and financial regulation.

Bibliography of Works Cited

\section{Books}

Bodenhorn, Howard. A History of Banking in Antebellum America: Financial Markets and Economic Development in an Era of Nation-Building. Cambridge: Cambridge University Press, 2000.

Calomiris, Charles W., and Stephen H. Haber. Fragile by Design: The Political Origins of Banking Crises and Scarce Credit. Princeton, NJ: Princeton University Press, 2014.

Collins, Michael, and Mae Baker. Commercial Banks and Industrial Finance in England and Wales, 1860-1913. Oxford: Oxford University Press, 2003.

Cassis, Youssef. Crises and Opportunities: The Shaping of Modern Finance. Oxford: Oxford University Press, 2011.

Fleming, Anne. City of Debtors: A Century of Fringe Finance. Cambridge, MA: Harvard University Press, 2018.

Gillman, Howard. The Constitution Besieged: The Rise \& Demise of Lochner Era Police Powers Jurisprudence. Durham, NC: Duke University Press Books, 1995.

Hyman, Louis. Debtor Nation: The History of America in Red Ink. Princeton, NJ: Princeton University Press, 2011.

Karsten, Peter. Heart versus Head: Judge-Made Law in Nineteenth-Century America. Chapel Hill: University of North Carolina Press, 2000.

Kostal, Rande W. Law and English Railway Capitalism, 1825-1875. Oxford: Clarendon Press, 1994.

Lewis, A. D. E., and Michael Lobban, eds. Law and History. Oxford: Oxford University Press, 2004.

Nelson, Scott Reynolds. A Nation of Deadbeats: An Uncommon History of America's Financial Disasters. New York: Knopf Doubleday Publishing Group, 2012.

Olegario, Rowena. The Engine of Enterprise: Credit in America. Cambridge, MA: Harvard University Press, 2016.

White, Eugene N. The Regulation and Reform of the American Banking System, 1900-1929. Princeton, NJ: Princeton University Press, 2016. 
Articles, Chapters in Books, Blogs, and Dissertations

Auchmuty, Rosemary, and Erika Rackley. "Feminist Legal Biography: A Model for All Legal Life Stories.” Journal of Legal History 41, no. 2 (2020): 186-211. https://doi.org/10.1080/01440365.2020.1783604.

Balleisen, Edward J. "In Memoriam: Anne C. Fleming, 1979-2020." The Exchange (blog). September 1, 2020. http://exchange-bhc.blogspot.com/ 2020/09/in-memoriam-anne-c-fleming-1980-2020.html.

Baradaran, Mehrsa. Review of "Anne Fleming, City of Debtors: A Century of Fringe Finance.” American Historical Review 123, no. 5 (2018): 1680-1681. https://doi.org/10.1093/ahr/rhy219.

Barnes, Victoria. "Judicial Intervention in Early Corporate Governance Disputes: Vice-Chancellor Shadwell's Lost Judgment in Mozley v. Alston (1847)." American Journal of Legal History 58, no. 3 (2018): 394-413. https://doi.org/10.1093/ajlh/njy010.

— Sean Bottomley, and Anselm Küsters. "Economic History as Legal History." Rechtsgeschichte - Legal History 27 (2019): 265-270.

Barnes, Victoria, Catharine MacMillan, and Stefan Vogenauer. "On Legal Biography.” Journal of Legal History 41, no. 2 (2020): 115-121. https://doi. org/10.1080/01440365.2020.1783603.

Barnes, Victoria, and Lucy Newton. "Symbolism in Bank Marketing and Architecture: The Headquarters of National Provincial Bank of England.” Management \& Organizational History 14, no. 3 (2019): 213-244. https://doi.org/ 10.1080/17449359.2019.1683038.

—. "Women, Uniforms and Brand Identity in Barclays Bank." Business History (forthcoming). https://doi.org/10.1080/00076791.2020.1791823.

Batlan, Felice. "The Birth of Legal Aid: Gender Ideologies, Women, and the Bar in New York City, 1863-1910." Law and History Review 28, no. 4 (2010): 931-971. https://doi.org/10.1017/S0738248010000726.

Benidickson, Jamie. "Aemilius Irving: Solicitor to the Great Western Railway, 1855-1872." In Inside the Law: Canadian Law Firms in Historical Perspective, edited by Carol Wilton, 100-121. Toronto: University of Toronto Press, 1996.

Bernstein, David E. “Bolling, Equal Protection, Due Process, and Lochnerphobia Essay: Fifty Years after Bolling v. Sharpe.” Georgetown Law Journal 93, no. 4 (2004- 2005): 1253-1286.

—_ "Lochner Era Revisionism, Revised: Lochner and the Origins of Fundamental Rights Constitutionalism.” Georgetown Law Journal 92, no. 1 (20032004): 1-60.

Carnevali, Francesca. “'Crooks, Thieves, and Receivers': Transaction Costs in Nineteenth-Century Industrial Birmingham." Economic History Review 57, no. 3 (2004): 533-550. https://doi.org/10.1111/j.1468-0289.2004.00287.x.

Clark, Gabrielle E. "The Southern and Western Prehistory of 'Liberty of Contract': Revisiting the Path to Lochner in Light of the New History of American Capitalism." American Journal of Legal History 60, no. 3 (2020): 253-283. https://doi.org/10.1093/ajlh/njaa014.

Collins, Michael. "The Growth of the Firm in the Domestic Banking Sector." In Business Enterprise in Modern Britain: From the Eighteenth to the Twentieth 
Century, edited by M. W. Kirby and Mary B. Rose, 263-286. Abingdon, UK: Routledge, 1994.

Cownie, Fiona. "The United Kingdom's First Woman Law Professor: An Archerian Analysis." Journal of Law and Society 42, no. 1 (2015): 127-149. https:// doi.org/10.1111/j.1467-6478.2015.00701.x.

Decker, Stephanie, Matthias Kipping, and R. Daniel Wadhwani. "New Business Histories! Plurality in Business History Research Methods.” Business History 57, no. 1 (2015): 30-40. https://doi.org/10.1080/00076791.2014.977870.

Delehanty, Sean. Review of "City of Debtors: A Century of Fringe Finance. Enterprise \& Society, 1-2. https://doi.org/10.1017/eso.2020.46.

Durepos, Gabrielle, Alan McKinlay, and Scott Taylor. "Narrating Histories of Women at Work: Archives, Stories, and the Promise of Feminism." Business History 59, no. 8 (2017): 1261-1279. https://doi.org/10.1080/ 00076791.2016.1276900.

Ernst, Daniel R. "In Memoriam: Professor Anne C. Fleming." Georgetown Law Journal 109, no. 1 (2020): 1-4.

— Karen Tani, and Mitra Sharafi. “Anne Fleming: In Memoriam.” Legal History Blog, August 26, 2020, http://legalhistoryblog.blogspot.com/2020/ 08/anne-c-fleming.html.

Fleming, Anne. "City of Debtors: Law, Loan Sharks, and the Shadow Economy of Urban Poverty, 1900-1970.” PhD diss., University of Pennsylvania, 2014.

— "City of Debtors: Law, Loan Sharks, and the Shadow Economy of Urban Poverty, 1900-1970." Enterprise \& Society 17, no. 4 (December 2016): 734-740. https://doi.org/10.1017/eso.2016.70.

—_. "Legal History As Economic History." In The Oxford Handbook of Legal History, edited by Markus D. Dubber and Christopher Tomlins, 201-220. Oxford: Oxford University Press, 2018.

— . "Protecting the Innocent: The Future of Mentally Disabled Tenants in Federally Subsidized Housing after HUD v. Rucker Note." Harvard Civil Rights-Civil Liberties Law Review 40, no. 1 (2005): 197-222.

- "The Borrower's Tale: A History of Poor Debtors in Lochner Era New York City." Law and History Review 30, no. 4 (2012): 1053-1098.

"The Long History of 'Truth in Lending."” Journal of Policy History 30, no. 2 (2018): 236-271. https://doi.org/10.1017/S0898030618000064.

- "The Public Interest in the Private Law of the Poor." Harvard Law $\&$ Policy Review 14 (2019-2020): 159-203.

- "The Rise and Fall of Unconscionability as the "Law of the Poor.", Georgetown Law Journal 102, no. 5 (2014): 1383-1442.

Guinnane, Timothy W. "Regional Organizations in the German Cooperative Banking System in the Late 19th Century." Research in Economics 51, no. 3 (1997): 251-274. https://doi.org/10.1006/reec.1997.0042.

Hahn, Barbara. Review of Emperors of New Clothes: Beckert, Baptist, and the New History of Capitalism, by Sven Beckert and Edward E. Baptist. Agricultural History 89, no. 3 (2015): 482-486.

Harris, Ron. "The Encounters of Economic History and Legal History." Law and History Review 21, no. 2 (2003): 297-346. https://doi.org/10.2307/3595094. 
Hilt, Eric. "Economic History, Historical Analysis, and the 'New History of Capitalism." Journal of Economic History 77, no. 2 (2017): 511-536. https://doi.org/10.1017/S002205071700016X.

Jong, Abe de, and David Michael Higgins. "New Business History?" Business History 57, no. 1 (January 2, 2015): 1-4. https://doi.org/10.1080/ 00076791.2014 .977868$.

Mitchener, Kris James. "Supervision, Regulation, and Financial Instability: The Political Economy of Banking during the Great Depression." Journal of Economic History 63, no. 2 (2003): 525-532.

Murphy, Sharon Ann. "Up Close and Personal with the American Debtor." Reviews in American History 47, no. 2 (2019): 236-242.

Newton, Lucy. "Regional Bank-Industry Relations during the Mid-Nineteenth Century: Links between Bankers and Manufacturing in Sheffield, c.1850 to c.1885." Business History 38, no. 3 (1996): 64-83. https://doi.org/ 10.1080/00076799600000095.

—. "Trust and Virtue in English Banking: The Assessment of Borrowers by Bank Managements at the Turn of the Nineteenth Century." Financial History Review 7, no. 2 (2000): 177-199. https://doi.org/10.1017/ S096856500000010X.

Nourse, Victoria F. "A Tale of Two Lochners: The Untold History of Substantive Due Process and the Idea of Fundamental Rights." California Law Review 97, no. 3 (2009): 751-800.

O'Sullivan, Mary. “The Intelligent Woman's Guide to Capitalism.” Enterprise $\&$ Society 19, no. 4 (2018): 751-802. https://doi.org/10.1017/eso.2018.96.

Popp, Andrew, and Susanna Fellman. "Writing Business History: Creating Narratives.” Business History 59, no. 8 (2017): 1242-1260. https://doi.org/ 10.1080/00076791.2016.1250742.

Posner, Eric A. "Contract Law in the Welfare State: A Defense of the Unconscionability Doctrine, Usury Laws, and Related Limitations on the Freedom to Contract." Journal of Legal Studies 24, no. 2 (1995): 283-319. https://doi. org/10.1086/467961.

Reveley, James, and John Singleton. "Clearing the Cupboard: The Role of Public Relations in London Clearing Banks' Collective Legitimacy-Seeking, 19501980.” Enterprise \& Society 15, no. 3 (2014): 472-498.

Rubin, Jared. "Bills of Exchange, Interest Bans, and Impersonal Exchange in Islam and Christianity." Explorations in Economic History 47, no. 2 (2010): 213-227. https://doi.org/10.1016/j.eeh.2009.06.003.

Salojärvi, Juhana. "A Counter-Culture of Law: Jurisprudential Change and the Intellectual Origins of the Critical Legal Studies Movement." American Journal of Legal History 59, no. 4 (2019): 409-443. https://doi.org/10.1093/ajlh/njz022.

Schnapp, Alexandra CC. Review of City of Debtors: A Century of Fringe Finance. American Bankruptcy Institute Journal 39, no. 3 (2020): 38-39.

Schweber, Howard. "Lochner v. New York and the Challenge of Legal Historiography.” Law \& Social Inquiry 39, no. 1 (2014): 242-274. https:// doi.org/10.1111/lsi.12062.

Scott, Peter. "The Twilight World of Interwar British Hire Purchase.” Past $\&$ Present 177, no. 1 (2002): 195-225. https://doi.org/10.1093/past/177.1.195. 
and Lucy Ann Newton. "Advertising, Promotion, and the Rise of a National Building Society Movement in Interwar Britain." Business History 54, no. 3 (2012): 399-423. https://doi.org/10.1080/00076791.2011.638489.

Selva, Simone. Review of City of Debtors: A Century of Fringe Finance. Economic History Review 73, no. 3 (2020): 878-880. https://doi.org/10.1111/ ehr.13017.

Stern, Simon. "Proximate Causation in Legal Historiography." History and Theory (forthcoming). https://doi.org/10.2139/ssrn.3708975.

Sugarman, David. "Simple Images and Complex Realities: English Lawyers and Their Relationship to Business and Politics, 1750-1950." Law and History Review 11, no. 2 (1993): 257-301. https://doi.org/10.2307/743616.

Sunstein, Cass R. “Lochner's Legacy.” Columbia Law Review 87, no. 5 (1987): 873-919.

Tanenhaus, David S. “In This Issue.” Law and History Review 30, no. 4 (2012): v-vii. https://doi.org/10.1017/S0738248012000818.

Waddams, S. M. "Unconscionability in Contracts." Modern Law Review 39, no. 4 (1976): 369-93.

Wadhwani, R. Daniel. "Citizen Savers: Family Economy, Financial Institutions, and Public Policy in the Nineteenth-Century Northeast." Enterprise $\&$ Society 5, no. 4 (December 2004): 617-624. https://doi.org/10.1017/ S1467222700014002. 